\title{
Clinical Expression of a Rare $\beta$-Globin Gene Mutation Co-Inherited with Haemoglobin E-Disease
}

\author{
Wouter W. van Solinge ${ }^{1}$, Bent Lind ${ }^{2}$, Richard van Wijk ${ }^{1}$, Herman Ch. Hart ${ }^{3}$ and Rob J. Krauijenhagen ${ }^{1}$ \\ ${ }^{1}$ Klinisch Laboratorium, Ziekenhuis Eemland, Amersfoort, Nederland \\ 2 Klinisk Biokemisk Afdeling, Rigshospitalet, København, Danmark \\ ${ }^{3}$ Interne Geneeskunde, Ziekenhuis Eemland, Amersfoort, Nederland
}

Summary: A single nucleotide substitution and the effect on the phenotype in an Indonesian family with $\beta$ thalassaemia, $\mathrm{HbE}$-trait and $\mathrm{HbE}-\beta$-thalassaemia is described. In the proposita (female, age $20(\mathrm{Hb} 7.4 \mathrm{mmol} / \mathrm{l}$; MCV $72 \mathrm{fl} ; \mathrm{MCH} 1.45 \mathrm{fmol} ; \mathrm{HbA}_{2} 3.5 \%$; $\left.\mathrm{HbF} 2.4 \%\right)$ ). an A/G mutation in the RNA cleavage and polyadenylation sequence was detected (AATAAAAAATAGA). Her sister ( $\mathrm{Hb} 8.2 \mathrm{mmol} / \mathrm{l} ; \mathrm{MCV} 77 \mathrm{fl} ; \mathrm{MCH} 1.60 \mathrm{fmol} ; \mathrm{HbA}_{2} / \mathrm{HbE}$ $32.4 \%$ ), carried a different mutation in the $\beta$-globin gene (codon $25 ; \mathrm{G}^{129} / \mathrm{A}$ ), and consequently had HbE-trait. Their mother had a haemoglobin concentration of $6.4 \mathrm{mmol} / 1$ (MCV $56 \mathrm{fl} ; \mathrm{MCH} 1.20 \mathrm{fmol} ; \mathrm{HbA}_{2} / \mathrm{HbE} 55.8 \%$ ). She was compound heterozygous for the mutation in the poly A-signal and HbE-trait. Using restriction enzyme analysis and linkage studies, we subsequently identified six family members with HbE- $\beta$-thalassaemia, five with $\beta$-thalassaemia and six with $\mathrm{HbE}$-trait. Two individuals were unaffected. The mutation in the polyadenylation sequence causes a mild form of $\beta^{+}$-thalassaemia. The $\mathrm{MCV}$ and $\mathrm{MCH}$ in individuals with both $\beta$-thalassaemia and $\mathrm{HbE}$-trait were significantly lower, yet on average they were only slightly more anaemic than those carrying only the thalassaemic gene.

\section{Introduction}

$\beta$-Thalassaemias constitute a heterogeneous group of genetic disorders that result from a reduced $\left(\beta^{+}\right)$or absent $\left(\beta^{0}\right)$ synthesis of $\beta$-globin chains, due to aberrant $\beta$-globin mRNA (1). Over 160 mutations causing a $\beta$-thalassaemia phenotype have been described; many of these are characteristic for the population in which they are observed (2). The disease has a considerable phenotypic variation depending on many factors including the nature of the mutation involved, co-inheritance of other genetic factors influencing non- $\beta$-globin synthesis (3) and presence of the mutation in the homo- or heterozygous state. Heterozygous patients are clincally asymptomatic and may have a microcytic, hypochromic anaemia, typically with elevated levels of haemoglobin $\mathrm{A}_{2}\left(\mathrm{HbA}_{2}\right)$ (4). Biochemical presentation, however, may also be normal or nearly normal, causing problems in diagnosis and hence in genetic counselling (5).

The common haemoglobinopathy haemoglobin $E$ $(\mathrm{HbE})$, is caused by a point mutation at codon 26 in the $\beta$-globin gene (G/A), resulting not only in a structural haemoglobin variant but also affecting mRNA splicing (6). The clinical phenotype is that of a mild form of $\beta$ thalassaemia (7). Consequently, inherited together with $\beta$-thalassaemia a marked deficit of $\beta$-chain production is to be expected, leading to a clinical picture of severe $\beta$-thalassaemia (8). In fact, $\mathrm{HbE}-\beta$-thalassaemia shows an extraordinary variability in clinical expression. $\mathrm{Pa}$ tients may be either severely affected or have a relatively mild clinical expression of the disease. This is due to the kind of mutation and/or to genetic modifiers linked to the globin gene clusters or located elsewhere in the genome.

Routinely, $\beta$-thalassaemia diagnosis is based on the detection of an elevated $\mathrm{HbA}_{2}$ using electrophoretic or chromatographic techniques. These techniques are commercially available and in general sufficient to correctly diagnose these disorders. However, when $\mathrm{HbA}_{2}$ fraction is normal and nevertheless there is suspicion of $\beta$-thalassaemia, other techniques for carrier detection should be used. $\mathrm{HbE}$ co-migrates with $\mathrm{HbA}_{2}$ in several electrophoretic systems, making the detection of compound heterozygotes for $\beta$-thalassaemia/HbE-trait difficult by routine analysis. In this study we used molecular biology techniques to solve these problems. A better insight into the clinical expression of specific mutations may be of importance in predicting the degree of clinical severity and influence the decisions concerning the prevention and the therapy of these diseases. We therefore characterized, on the molecular and biochemical level, a rare mutation in the $\beta$-globin gene in an Indonesian family with $\beta$-thalassaemia, $\mathrm{HbE}$-trait and $\mathrm{HbE}-\beta$-thalassaemia. 


\section{Materials and Methods}

Patients

Subjects under study were the proband and her family (her grandparents, their nine children and nine grandchildren; for age and gender data sce tabs. 1-3). Informed consent was obtained from all subjects.

\section{Biochemical and haematological assays}

Haemoglobin concentration, red cell indices and erythrocytes were measured using an automated cell counter (Sysmex Toa E-5000, Toa Medical Electronics, Kobe, Japan). Reticulocyte count was performed by flow cytometric analysis (Sysmex R-1000, Toa Medical Electronics, Kobe, Japan). Iron status was evaluated by measuring serum ferritin (radioimmunoassay, Diagnostic Products Corporation, Los Angeles, CA. USA), serum iron and serum transferrin using a Hitachi 717 (Boehringer Mannheim, Germany). Haemoglobin molecules were separated by gel electrophoresis at $\mathrm{pH} 8.5$ using the Beckman Paragon System according to the instructions of the manufacturer (Beckman Instruments, Brea, CA, USA). Electrophoresis was carried out on $3 \mu l$ of haemolyzed washed red cells for 25 minutes at $150 \mathrm{~V}$. Dried gels were scanned at $595 \mathrm{~nm}$. HPLC was carried out using the MDMS-modular system (BioRad, Veenendaal, The Netherlands), with an analytical cation exchange column, according to the instructions of the manufacturer.

\section{Isolation of genomic DNA}

Blood for extraction of genomic DNA was collected in tubes containing $\mathrm{K}_{3}$-EDTA at a final concentration of $3.9 \mathrm{mmol} / \mathrm{l}$. The DNA was isolated using a commercial DNA extraction kit (Stratagene; cat. No. 200600), according to the instructions of the manufacturer.

\section{Polymerase chain reaction (PCR) of genomic DNA}

Two specific fragments (designated $5^{\prime}$ and $3^{\prime}$ ) of the $\beta$-globin gene were amplified by the polymerase chain reaction using two oligonucleotide primer sets: EC-1/2 and EC-3/4.

EC-1/2:

sense 5'-CCCTGTGGAGCCACACCCTA-3' and antisense 5'-ACGATCCTGAGACTTCCACAC-3'

amplify the 5 -fragment of 742 base pairs from nt-103, relative to the cap site, to nt 144 of IVS-II.')

EC-3/4:

sense 5'-TGCCTCTTTGCACCATTCTAAAG-3' and antisense 5'-TGCACTGACCTCCCACATTCC-3'

amplify the 3'-fragment of 571 base pairs from IVS-II nt 603 to nt +194 , relative to the termination codon. For detection of the codon $26 \mathrm{G} / \mathrm{A}$ mutation, we used a primer set to generate a 338 base pair fragment, from $n t-19$ relative to the cap site, to codon 46 in the second exon: EG1/2.

EG1/2:

sense 5'-GCAGAGCCATCTATTGCTTAC-3' and antisense 5'-CCAAAGGACTCAAAGAACCTC-3'.

PCR was performed using the DNA thermal cycler 9600 (Perkin Elmer (Norwalk, CT)) in $100 \mu \mathrm{l}$ volumes containing $10 \mathrm{mmol} / \mathrm{l}$ Tris- $\mathrm{HCl}, \mathrm{pH} 8.3,50 \mathrm{mmol} / \mathrm{K} \mathrm{KCl}, 1.5 \mathrm{mmol} / 1 \mathrm{MgCl}_{2}, 0.1 \mathrm{~g} / 1$ gelatine, $0.2 \mathrm{mmol} / \mathrm{l}$ of each dNTP, $1 \mu \mathrm{mol} / 1$ of each primer, $\sim 5 \mu \mathrm{g}$ genomic DNA, and 2.5 U AmpliTaq DNA polymerase. All reagents were obtained from Perkin Elmer. The samples were subjected to 30 cycles of amplification with denaturation at $94^{\circ} \mathrm{C}$ for 1 minute ( 5 minutes at $95^{\circ} \mathrm{C}$ in the first cycle), annealing at $64^{\circ} \mathrm{C}$ for 1 minute and extension at $72{ }^{\circ} \mathrm{C}$ for 1 minute followed by an elongated extension time of 7 minutes after the last cycle. Negative

') Abbreviations:

MCV: mean corpuscular volume

$\mathrm{MCH}$ : mean corpuscular haemoglobin

RDW: red cell distribution width

IVS: intervening sequence controls, without added DNA, were included in each run to exclude amplification of contaminating DNA. Twenty $\mu$ l of the amplified PCR product was electrophorescd on a $30 \mathrm{~g} /$ agarose-gel and visualized using ethidium bromide. The $\varphi$ X174 DNA-HaeIII digest from Promega was used as relative molecular mass marker.

The $\alpha$-globin gene clusters were screened for deletions using PCR, according to Bowden et al. (9) and Dodé et al. (10).

\section{Restriction enzyme analysis}

To demonstrate the presence of the codon $26 \mathrm{G} / \mathrm{A}$ mutation causing $\mathrm{HbE}, 20 \mu \mathrm{l}$ of the amplified fragment was digested with $20 \mathrm{U}$ of $H p h I$ (New England Biolabs), according to the manufacturer's instructions, for 2 hours at $37^{\circ} \mathrm{C}$. Restriction fragments were electrophoresed and visualized as described above. Normal $\beta$-globin PCRfragments contain two recognition sites for this restriction enzyme $\left.\left(5^{\prime}-\text { GGTGA(N) }\right)_{8} /-3^{\prime}\right)$, while PCR-fragments with the codon $26 \mathrm{G} / \mathrm{A}$ mutation have one such site. For detection of the polymorphisms at codon $2(\mathrm{C} / \mathrm{T})$ and IVS-2; nt $16(\mathrm{C} / \mathrm{G})$, we digested $20 \mu \mathrm{l}$ of the 5 -fragment with $20 \mathrm{U}$ of BsiHKAI and AvalI (New England Biolabs) respectively, under the conditions as described for $H p h \mathrm{I}$. BsiHKAI recognizes 5'-G[A,T]GC[A,T]/C-3' and AvaII ' 5'-G/ $\mathrm{G}[\mathrm{A}, \mathrm{T}] \mathrm{CC}-\mathrm{3}^{\prime}$. Presence of homozygous $\mathrm{T}$ in codon 2 results in two restriction fragments using BsiHKAI, while homozygous $C$ results in three fragments. PCR-fragments homozygous for $G$ at position IVS-2; nt 16 are cleaved into two fragments using Avall and into three fragments when homozygous for $\mathrm{C}$.

Purification and nucleotide sequencing of PCRamplified $\beta$-globin DNA segments

Amplified genomic DNA segments were electrophoresed as described under $P C R$ of genomic DNA, and isolated from the gel using the Prep-A-Gene DNA purification kit (BioRad). Singlestranded DNA for nucleotide sequencing was prepared by asymmetric PCR using the same reaction conditions as described for PCR of genomic DNA except that in each reaction one of the two primers was in excess (primer concentrations $0.5 \mu \mathrm{mol} / 1$ and 0.01 $\mu \mathrm{mol} / \mathrm{l}$, respectively); the template DNA used was $50 \mathrm{ng}$ of isolated double-stranded DNA and the concentration of each dNTP was decreased to $0.05 \mathrm{mmol} / \mathrm{l}$. To remove excess $\mathrm{dNTP}$ and to concentrate the single-stranded DNA in the asymmetric PCR product it was filtered through Ultrafree MC 30.000 NMWL filter units (Millipore, Bedford, MA, USA). Nucleotide sequencing was performed using Sequenase, kit version 2.0 (US Biochemicals, Cleveland, $\mathrm{OH}, \mathrm{USA}$ ) and relevant oligonucleotides.

\section{Results}

\section{Clinical and biochemical characterization}

The results of the family investigations are presented in tables $1-3$. The proposita (tab. 1, family member 13 ) is a Dutch female of Indonesian origin. At 20 years of age she was admitted to the hospital for unexplained fatigue and loss of weight. Repeated laboratory analysis of the blood showed a normal to mildly decreased haemoglobin ( $7.4 \mathrm{mmol} / \mathrm{l}$; for reference values see tab. 1), slightly microcytic $(72 \mathrm{fl})$ and hypochromic red cells $\left(\mathrm{MCH}^{\mathrm{l}}\right)$ $1.45 \mathrm{fmol})$. Haemoglobin electrophoresis indicated a marginally elevated $\mathrm{HbA}_{2}$ of $3.5 \%$ and haemoglobin $\mathrm{F}$ of $2.4 \%$. There was no iron deficiency (iron, ferritin, transferrin and C-reactive protein within the reference range) and no indication of haemolysis (bilirubin, haptoglobin and reticulocytes all normal). Liver and spleen were not enlarged. 
Her mother, a woman of Indonesian origin (tab. 3; family member 4 ), had a concentration of $6.4 \mathrm{mmol} / \mathrm{l}$, with a markedly decreased $\mathrm{MCV}^{1}$ ) of $56 \mathrm{fl}$ and $\mathrm{MCH}$ of $1.20 \mathrm{fmol}$. Haemoglobin electrophoresis indicated a distinctly elevated fraction of $\mathrm{HbA}_{2} / \mathrm{HbE}(55.8 \%)$ and an elevated fraction of $\mathrm{HbF}$ of $3.3 \%$. Reticulocytes $(4.1 \%)$ and bilirubin $(60 \mu \mathrm{mol} / \mathrm{l})$ were elevated, haptoglobin concentration was decreased $(0.3 \mathrm{~g} / \mathrm{l})$. Liver and spleen were not enlarged, as shown by ultrasound techniques. During her two pregnancies the haemoglobin concentration dropped to $4.5 \mathrm{mmol} / \mathrm{l}$, but no transfusions were given.

The only sister of the proposita (tab. 2; family member 12) had no anaemia ( $\mathrm{Hb} 8.2 \mathrm{mmol} / \mathrm{l}$ ), but marginally decreased red cell indices (MCV $77 \mathrm{fl}$; $\mathrm{MCH} 1.60 \mathrm{fmol}$ ). Haemoglobin electrophoresis showed a band of $32.4 \%$ migrating in the $\mathrm{HbA}_{2}$ region and an $\mathrm{HbF}$-band of $1.8 \%$. She was healthy and liver and spleen were not enlarged. The father of the proposita was not available for examination.

On the basis of the clinical, haematological and biochemical data, we concluded the presence of a haemoglobinopathy in the sister of the proposita. Since the haematological abnormalities were more pronounced in the mother we postulated the presence of a second mutation in (most likely) her $\beta$-globin genes. We concluded the proposita had a mild form of $\beta$-thalassaemia, inherited from her mother.

Tab. 1 Family members with $\beta$-thalassaemia

\begin{tabular}{|c|c|c|c|c|c|c|c|c|}
\hline \multirow{3}{*}{$\begin{array}{l}\text { Family member } \\
\text { Age (years) } \\
\text { Sex }\end{array}$} & \multirow{3}{*}{$\begin{array}{l}1 \\
62 \\
q\end{array}$} & \multirow{3}{*}{$\begin{array}{l}7 \\
36 \\
q\end{array}$} & \multirow{3}{*}{$\begin{array}{l}13^{*} \\
20 \\
9\end{array}$} & \multirow{3}{*}{$\begin{array}{l}15 \\
14 \\
\delta^{\prime}\end{array}$} & \multirow{3}{*}{$\begin{array}{l}17 \\
18 \\
9\end{array}$} & \multirow{3}{*}{$\begin{array}{l}18 \\
4 \\
\delta\end{array}$} & \multicolumn{2}{|c|}{ Reference values } \\
\hline & & & & & & & & \\
\hline & & & & & & & q & $\hat{\sigma}$ \\
\hline $\mathrm{Hb}(\mathrm{mmol} / \mathrm{l})$ & 7.7 & 7.6 & 7.4 & 8.1 & 8.1 & 6.5 & $7.8-10.0$ & $8.5-10.5$ \\
\hline Erythrocytes $\left(10^{12} / \mathrm{I}\right)$ & 4.96 & 4.98 & 5.10 & 5.64 & 5.09 & 4.46 & $4-5.5$ & $4.4-5.8$ \\
\hline $\operatorname{MCV}(f l)$ & 78 & 74 & 72 & 72 & 77 & 72 & $80-102$ & $80-102$ \\
\hline $\mathrm{MCH}$ (fmol) & 1.55 & 1.53 & 1.45 & 1.44 & 1.59 & 1.46 & $1.8-2.2$ & $1.8-2.2$ \\
\hline $\mathrm{RDW}(\mathrm{fl})$ & 24.9 & 25.8 & 22.5 & 23.2 & 23.7 & 23.7 & $23-36$ & $23-36$ \\
\hline Reticulocytes (\%) & 1.2 & 2.1 & 2.0 & 1.5 & 1.6 & 1.9 & $0.4-2$ & $0.4-2$ \\
\hline $\mathrm{HbA}_{2}(\%)$ & 4.4 & 4.5 & 3.5 & 4.5 & 4.1 & 4.6 & $<3.2$ & $<3.2$ \\
\hline $\mathrm{HbF}(\%)$ & 1.2 & 0.9 & 2.4 & 1.0 & 2.0 & 1.1 & $<1.0$ & $<1.0$ \\
\hline
\end{tabular}

Tab. 2 Family members with $\mathrm{HbE}$

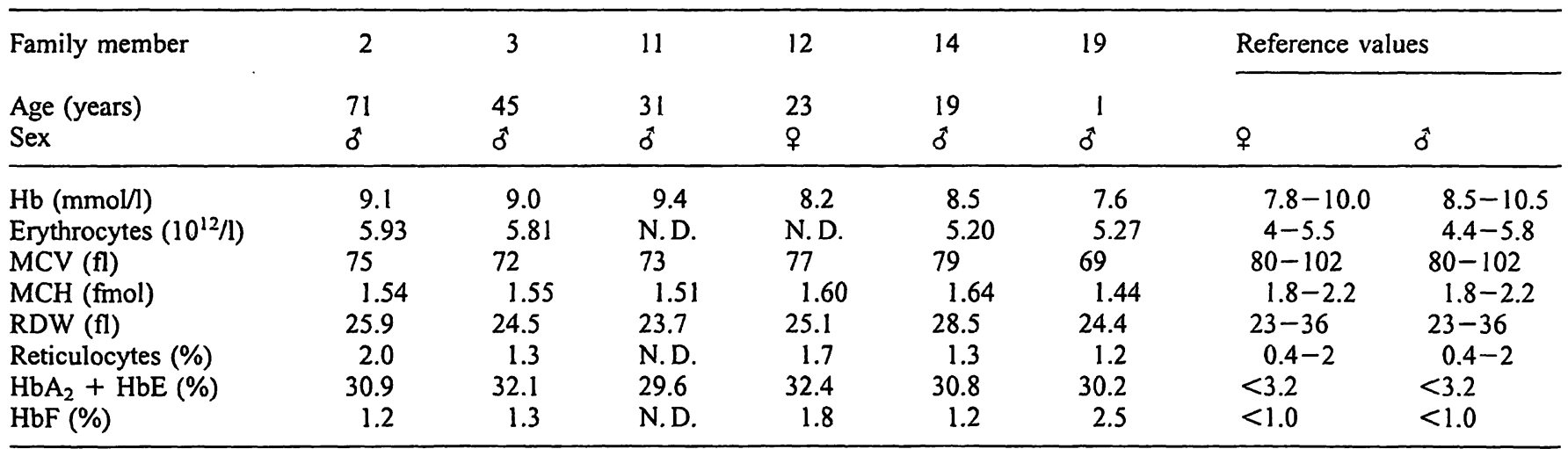

N.D.: not determined.

Tab. 3 Family members with $\beta$-thalassaemia and $\mathrm{HbE}$

\begin{tabular}{|c|c|c|c|c|c|c|c|c|}
\hline \multirow{2}{*}{$\begin{array}{l}\text { Family member } \\
\text { Age (years) } \\
\text { Sex }\end{array}$} & \multirow{2}{*}{$\begin{array}{l}4 \\
43 \\
q\end{array}$} & \multirow{2}{*}{$\begin{array}{l}5 \\
41 \\
9\end{array}$} & \multirow{2}{*}{$\begin{array}{l}6 \\
37 \\
\delta\end{array}$} & \multirow{2}{*}{$\begin{array}{l}8 \\
35 \\
\delta\end{array}$} & \multirow{2}{*}{$\begin{array}{l}9 \\
33 \\
0\end{array}$} & \multirow{2}{*}{$\begin{array}{l}10 \\
32 \\
\$\end{array}$} & \multicolumn{2}{|c|}{ Reference values } \\
\hline & & & & & & & q & $\hat{0}$ \\
\hline $\begin{array}{l}\mathrm{Hb}(\mathrm{mmol} / \mathrm{l}) \\
\text { Erythrocytes }\left(10^{12} / \mathrm{l}\right) \\
\mathrm{MCV}(\mathrm{fl}) \\
\mathrm{MCH}(\mathrm{fmol}) \\
\text { RDW (fl) } \\
\text { Reticulocytes (\%) } \\
\mathrm{HbA}_{2}+\mathrm{HbE}(\%) \\
\mathrm{HbF}(\%)\end{array}$ & $\begin{array}{c}6.4 \\
5.35 \\
56 \\
1.20 \\
20.6 \\
4.1 \\
55.8 \\
3.3\end{array}$ & $\begin{array}{c}6.2 \\
5.06 \\
61 \\
1.23 \\
22.7 \\
4.3 \\
53.1 \\
3.7\end{array}$ & $\begin{array}{c}7.4 \\
6.57 \\
57 \\
1.13 \\
22.6 \\
2.2 \\
53.3 \\
1.2\end{array}$ & $\begin{array}{l}7.9 \\
6.47 \\
61 \\
1.22 \\
22.0 \\
2.7 \\
55.9 \\
1.5\end{array}$ & $\begin{array}{l}8.1 \\
6.91 \\
58 \\
1.17 \\
22.2 \\
2.7 \\
53.2 \\
2.3\end{array}$ & $\begin{array}{l}7.1 \\
6.11 \\
58 \\
1.16 \\
21.2 \\
2.9 \\
54.1 \\
2.1\end{array}$ & $\begin{array}{l}7.8-10.0 \\
4-5.5 \\
80-102 \\
1.8-2.2 \\
23-36 \\
0.4-2 \\
<3.2 \\
<1.0\end{array}$ & $\begin{array}{c}8.5-10.5 \\
4.4-5.8 \\
80-102 \\
1.8-2.2 \\
23-36 \\
0.4-2 \\
<3.2 \\
<1.0\end{array}$ \\
\hline
\end{tabular}




\section{Gene analysis}

Fragments of the $\beta$-globin gene of the proposita were PCR-amplified using primers EC-1/2 and EC-3/4. Direct sequencing revealed a mutation in the RNA cleavage and polyadenylation sequence-(AATAAA/AATAGA). No other mutations could be identified in the gene. In addition, known $\beta$-globin gene polymorphisms were detected at codon $2(\mathrm{C} / \mathrm{C})$ and IVS-2; nt $16(\mathrm{C} / \mathrm{C})$. $\beta$-Globin genes of the grandparents (family members 1 and 2 ) were subsequently amplified and sequenced. The grandfather (family member 2) was heterozygous for the known codon 26 mutation causing haemoglobin $\mathrm{E}$ $(\mathrm{HbE})$. The $\beta$-globin gene polymorphisms (vide supra) were $T / T$ (codon 2 ) and G/G (IVS-2; nt 16). In the $\beta$ globin gene of the grandmother (family member 1) the same mutation as in the proposita was detected (AATAAA/AATAGA). The $\beta$-globin gene polymorphisms were $C / C$ (codon 2) and C/C (IVS-2; nt 16).

Since the electrophoretic and chromatographic systems used cannot separate $\mathrm{HbA}_{2}$ and $\mathrm{HbE}$ from each other, we devised a strategy using elementary molecular biology techniques in order to characterize the $\beta$-globin genes of other family members. The codon 26 mutation causing haemoglobin $\mathrm{E}$ was detected by demonstration of the loss of an $H p h \mathrm{I}$ restriction site. This mutation was present in twelve family members (tabs. 2 and 3; family members $2-6,8-12,14$ and 19). For the mutation in the RNA cleavage and polyadenylation sequence (AATAAA/AATAGA), no restriction enzyme is available to date. To avoid extensive DNA-sequencing we aimed at demonstrating linkage between the detected polymorphisms and the mutations in the $\beta$-globin genes. If this was so, we could use restriction enzyme analysis to demonstrate the presence of the AATAAA/AATAGA mutation. For second generation individuals this was not possible, since they all were heterozygous for both polymorphisms. We had to make one assumption, that judging from the biochemical data, family members with unusually high $\mathrm{HbE} /$ $\mathrm{HbA}_{2}$ fraction (tab. 3) would be compound heterozygotes, since we knew from $H p h I$ analysis they at least carried the codon 26 mutation. To test this assumption we sequenced the $\beta$-globin gene fragments of family members numbers 4 (mother of the proposita), 5, 6, 8, and 9. They were shown to carry both mutation in trans and were heterozygous for both polymorphisms. The gene of family member number 7 was also sequenced and only the AATAAA/ AATAGA mutation was detected. She was heterozygous for both polymorphisms. By use of restriction enzyme analysis it was shown that the codon 26 mutation causing $\mathrm{HbE}$ was linked to a $\mathrm{T}$ in codon 2 (fig. 1) and a $\mathrm{G}$ at nucleotide 16 in IVS-2. The AATAAA/AATAGA mutation cosegregated with a $C$ in codon 2 (fig. 1 ) and a $C$ at position 16 in IVS-2. We characterized the third generation of the family on the molecular level using linkage of the mutations to the gene polymorphisms.
Out of 20 family members we identified 6 with $\mathrm{HbE}-\beta$ thalassaemia, 6 with $\beta$-thalassaemia and 6 with $\mathrm{HbE}$ trait. Two individuals were unaffected (fig. 2). The biochemical presentation of each group of patients was remarkably homogeneous, except for the proposita with only slightly elevated levels of $\mathrm{HbA}_{2}$ (tabs. $1-3$ ). The molecular diagnosis correlated with the diagnosis based on the clinical and biochemical data.

No $\alpha$-globin gene deletions were detected in this family as determined by PCR techniques. ,

\section{Discussion}

Difficulty in diagnosing $\beta$-thalassaemia in individuals with borderline or only slightly elevated $\mathrm{HbA}_{2}$ levels is not uncommon. The proposita described in this study was only slightly anaemic, her MCV and $\mathrm{MCH}$ were lowered and the fraction of $\mathrm{HbA}_{2}$ was marginally ele-
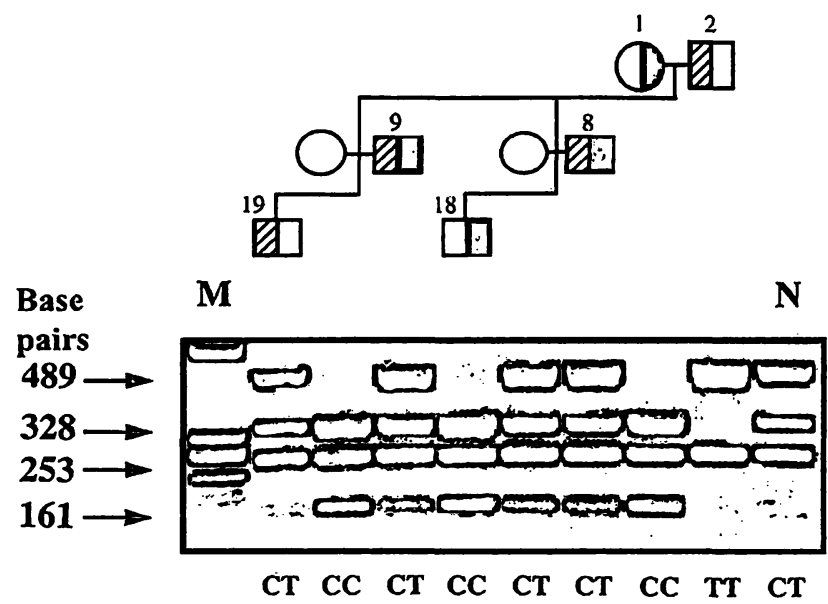

Fig. 1 Linkage of the $\beta$-thalassaemia mutation (black area in pedigree) and the haemoglobin $\mathrm{E}$ mutation (hatched area in pedigree) to the gene polymorphism in codon $2(\mathrm{C} / \mathrm{T})$, using restriction enzyme (BsiHKI) analysis. Numbers in pedigree corresponds to family numbers. $\mathrm{M}$ : molecular size marker. $\mathrm{N}$ : normal heterozygous control.

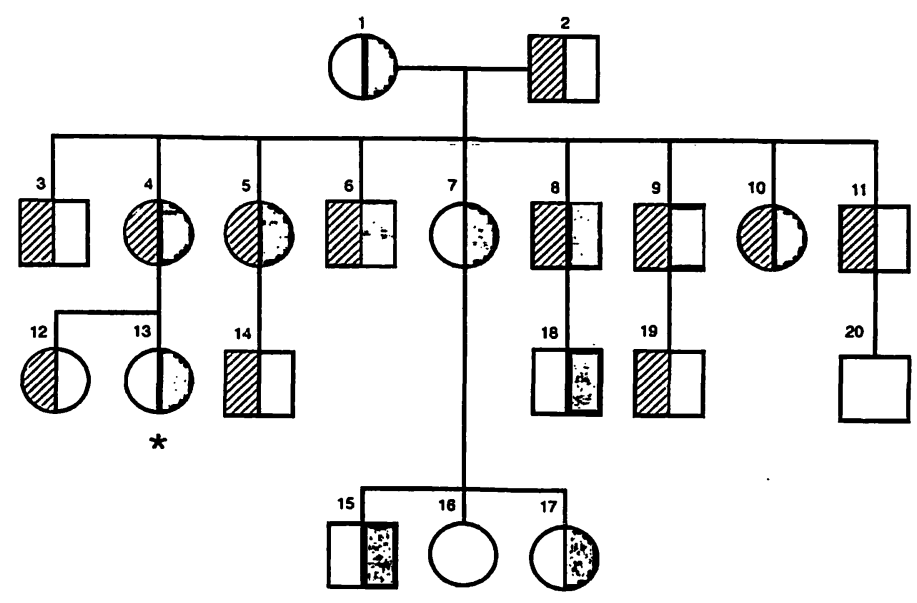

Fig. 2 Pedigree of an Indonesian family showing all genetically related individuals. Squares denote males, circles females. Hatched area indicates heterozygote for haemoglobin E; black area indicates heterozygote for $\beta$-thalassaemia; white area symbolizes normal $\beta$ globin gene(s).

* indicates the proposita. 
vated. Consequently, the final diagnosis remained uncertain. We chose to screen her mother and only sister to detect any haematological abnormality, in order to elucidate a possible genetic origin for the observed properties. The results of this screening prompted us to sequence the $\beta$-globin gene of the proposita. The detected mutation in the RNA cleavage and polyadenylation sequence (AATAAA/AATAGA) has been described once before, but no haematological data were presented for the heterozygous patient (11). As shown here in six related individuals, the mutation causes a mild form of $\beta^{+}$-thalassaemia. On average, haemoglobin concentrations are in the lower part of the reference range. $\mathrm{MCV}$ and $\mathrm{MCH}$ values are decreased. All patients except the proposita had clearly elevated $\mathrm{HbA}_{2}$ concentrations.

We demonstrate here that linkage studies, using restriction enzyme analysis, provide a useful method for the molecular diagnosis of $\beta$-thalassaemia in this family, allowing simple detection of the disease even in neonatal individuals. Similar approaches might be applicable for a variety of other genetic diseases.

3'-End processing of newly formed RNA transcripts consists of endonucleolytic cleavage of the primary transcript followed by polyadenylation of the upstream fragment $(12,13)$. This cleavage is directed by several sequence elements in the RNA. The upstream AAUAAA sequence is highly conserved and is located $10-30 \mathrm{nu}-$ cleotides upstream from the poly(A) addition site (12). Many mutagenesis experiments and analysis of naturally occuring mutations have shown that this hexanucleotide is essential for proper cleavage. Six different mutations in this element in the $\beta$-globin gene have been described to date, but their occurence is uncommon. Two deletions (AATAAAVAAAA (14); AATAAA/A (15) and four point mutations (AATAAA/AACAAA (16); AATAAAV AATGAA and AATAAA/AATAGA (11); AATAAA/ AATAAG (17) have been published to date. The mutation AATAAA/AATGAA was also described in a homozygous condition (18). The mutations lead to $\beta^{+}$-thalassaemia and even the homozygous patient expressed a mild form of $\beta$-thalassaemia. Rund et al. have shown in three patients in which the mutated AATAAG allele was the only gene capable of producing RNA for $\beta$-globin, an expression of $12-34 \%$ of normally cleaved and polyadenylated $\beta$-globin mRNA (15). This indicated that this particular type of mutation does not totally abolish cleavage and polyadenylation. In addition, several studies have shown the existence of multiple elongated $\beta$-globin mRNA's in patients carrying mutations in the poly(A) signal, indicating the use of alternative downstream AATAAA sites $(15,16)$. It was suggested (16) and concluded (15) that part of these transcripts were translated, although inefficiently.
The effect on the mRNA level of the poly A mutation described here has not been reported. As judged from the phenotype of the six patients in our study, a similar effect of this mutation on the expression of the gene might be anticipated. However, comparison of our data with the haematological data presented for the female patient heterozygous for the mutation AATAAA/AATGAA (18), does show a milder phenotype associated with the latter ( $\mathrm{Hb} 8.7 \mathrm{mmol} / \mathrm{l}, \mathrm{MCV} 83 \mathrm{fl}, \mathrm{HbA}_{2} 3.7 \%$ ). Three patients heterozygous for AATAAA/AATGAA as described by Jancovic et al. (11), express phenotypes comparable with the patients described in the present study. This indicates that phenotypic expression of a specific mutation is not only dependent on the kind of mutation, but in addition is influenced by a variety of other genetic factors $(2,19)$. Studies on the RNA level are needed to confirm the hypothesized molecular mechanisms explaining the relation between this genotype and its effects.

Six other members of the family under investigation are carriers of a G/A mutation in codon 26 and consequently have HbE-trait. They have normal haemoglobin concentrations, but lowered $\mathrm{MCV}$ and $\mathrm{MCH}$ values. The mutation results in the structurally abnormal haemoglobin $\mathrm{E}$. In addition, a cryptic splice site is created, leading to a diminished production of $\beta^{E}$-globin, which explains the clinical phenotype of a mild $\beta$-thalassaemia $(6,20)$. Consequently, when inherited together with $\beta$-thalassaemia, a marked deficit of $\beta$-chain production and a clinical phenotype of severe $\beta$-thalassaemia might be expected (8). In fact, the clinical expression of this disorder varies widely, due to e.g. co-inheritance of $\alpha$-thalassaemia (19), kind of $\beta$-globin gene mutations $(21,22)$ and other genetic factors (2). The six patients in the present study who had $\beta$-thalassaemia/HbE-trait, expressed a mild disease. Two patients with the lowest haemoglobin concentrations had relatively high $\mathrm{HbF}$ levels and reticulocyte counts. Possibly an additional genetic factor located outside the sequenced segment of the $\beta$-globin gene or $\alpha$-globin genes is responsible for this phenomenon. Additional studies are necessary to identify, if present, such a factor. To our knowledge only one patient has been described with identical mutations in the $\beta$ globin genes (11). Comparison of the haematological data on the six members of the described family who have $\beta$-thalassaemia/ $\mathrm{HbE}$ trait (tab. 3), with the data of the previously published patient, illustrate the influence of other genetic factors on the phenotype. This patient had a haemoglobin of $5.9 \mathrm{mmol} / \mathrm{l}$, significantly lower than the male patients published here. MCV was similar (59 fl), but his $\mathrm{HbF}$ fraction was clearly higher (7.6\%). Even considering the low $\mathrm{MCV}$ and $\mathrm{MCH}$ values, the phenotypic expression of the combined disease in our patients is surprisingly mild. Although we have not identified ameliorating factors, the presence of such modifiers in the described family is feasible. 


\section{References}

1. Thein SL. $\beta$-Thalassemia. In: Bailliere's clinical haematology. The haemoglobinopathies. Philadelphia: Saunders, 1993; $6: 151-75$.

2. Kazazian Jr HH. The thalassemia syndromes: molecular basis and prenatal diagnosis in 1990. Semin Hematol 1990; 27:209-28.

3. Loukopoulos D. Thalassemia: genotype and phenotypes. Ann Hematol 1991; 62:85-94.

4. Rosatelli C, Leoni GB, Tuveri T, Scalas MT, Mosca A, Galanello $R$, et al. Heterozygous $\beta$-thalassemia: relationship between the hematological phenotype and the type of $\beta$-thalassemia mutation. Am J Hematol 1992; 39:1-4.

5. Pirastu M, Ristaldi MS, Loudianos G, Murru S, Sciarratta GV, Parodi MI, et al. Molecular analysis of atypical $\beta$-thalassemia heterozygotes. Ann NY Acad Sci 1990; 612:90-7.

6. Orkin SH, Kazazian Jr HH, Antonarakis SE, Ostrer H, Goff SC, Sexton JP. Abnormal RNA processing due to the exon mutation of $\beta^{\mathrm{E}}$-globin gene. Nature $1982 ; 300: 768-9$.

7. Adams III JG, Coleman MB. Structural hemoglobin variants that produce the phenotype of thalassemia. Semin Hematol $1990 ; 27: 229-38$.

8. Benz Jr EJ, Berman BW, Tonkonow BL, Coupal E, Coates $\mathrm{T}$, Boxer LA, et al. Molecular analysis of the $\beta$-thalassemia phenotype associated with inheritance of hemoglobin $E\left(\alpha_{2} \beta_{2}\right.$ ${ }^{26} \mathrm{Glu} \rightarrow$ Lys). J Clin Invest 1981; 68:118-26.

9. Bowden DK, Vickers MA, Higgs DR. A PCR-based strategy to detect the common severe determinants of $\alpha$ thalassaemia. Br J Haematol 1992; 81:104-8.

10. Dodé C, Krishnamoorthy R, Lamb J, Rochette J. Rapid analysis of $-\alpha^{3.7}$ thalassaemia and $\alpha \alpha \alpha^{\text {anti }} 3.7$ triplication by enzymatic amplification analysis. Br J Haematol 1992; 82:105-11.

11. Jankovic L; Efremov GD, Petkov G, Kattamis C, George E, Yang K-G, et al. Two novel polyadenylation mutations leading to $\beta^{+}$-thalassaemia. $\mathrm{Br} \mathrm{J}$ Haematol $1990 ; 75: 122-6$.

12. Wahle E, Keller W. The biochemistry of 3'-end cleavage and polyadenylation of messenger RNA precursors. Annu Rev Biochem 1992; 61:419-40.

13. Jackson RJ, Standart N. Do the poly(A) tail and 3' untranslated region control mRNA translation? Cell 1990; 62:15-24.
14. Huisman THJ. The $\beta$ - and $\delta$-thalassemia repository. Hemoglobin 1992; 16:237-58.

15. Rund D, Dowling C, Najjar K, Rachmilewitz EA, Kazazian Jr $\mathrm{HH}$, Oppenheim A. Two mutations in the $\beta$-globin polyadenylation signal reveal exterided transcripts and new RNA polyadenylation sites. Proc Natl Acad Sci USA 1992; 89:4324-8.

16. Orkin SH, Cheng T-C, Antonarakis SE, Kazazian Jr HH. Thalassemia due to a mutation in the cleavage-polyadenylation signal of the human $\beta$-globin gene. EMBO J 1985; 4:453-6.

17. Rund D, Cohen T, Filon D, Dowling CE, Warren TC, Barak I, et al. Evolution of a genetic disease in an ethnic isolate: $\beta$ thalassemia in the Jews of Kurdistan. Proc Natl Acad Sci USA $1991 ; 88: 310-4$.

18. Losekoot $M$, Fodde $R$, Harteveld $C L$, van Heeren $H$, Giordano PC, Went LN, et al. Homozygous $\beta^{+}$thalassaemia owing to a mutation in the cleavage-polyadenylation sequence of the human $\beta$ globin gene. J Med Genet 1991; 28:252-5.

19. Winichagoon $P$, Thonglairoam V, Fucharoen S, Wilairat $P$, Fukumaki Y, Wasi P. Severity differences in $\beta$-thalassaemia/haemoglobin $\mathrm{E}$ syndromes: implication of genetic factors. $\mathrm{Br} \mathrm{J}$ Haematol 1993; 83:633-9.

20. Traeger J, Wood G, Clegg JB, Weatherall DJ, Wasi P. Defective synthesis of $\mathrm{HbE}$ is due to reduced levels of $\beta^{\mathrm{E}} \mathrm{mRNA}$. Nature 1980; 288:497-9.

21. Fucharoen G, Fucharoen S, Jetsrisuparb A, Fukumaki Y. Molecular basis of $\mathrm{HbE}-\beta$-thalassemia and the origin of $\mathrm{HbE}$ in northeast Thailand: identification of one novel mutation using amplified DNA from buffy coat specimens. Biochem Biophys Res Commun 1990; 170:698-704.

22. Yang KG, Kutlar F, George E, Wilson JB, Kutlar A, Stoming $\mathrm{TA}$, et al. Molecular characterization of $\beta$-globin gene mutations in Malay patients with $\mathrm{HbE}-\beta$-thalassaemia and thalassaemia major. Br J Haematol 1989; 72:73-80.

Received May 27/September 18, 1996

Corresponding author: Dr. Wouter W. van Solinge, Clinical Laboratory, Eemland Hospital, Utrechtseweg 160, NL-3818 ES Amersfoort, The Netherlands 